\title{
Corticotropin-Releasing Hormone Directly Activates Noradrenergic Neurons of the Locus Ceruleus Recorded In Vitro
}

\author{
Hank P. Jedema ${ }^{1}$ and Anthony A. Grace ${ }^{1,2,3}$ \\ Departments of ${ }^{1}$ Neuroscience, ${ }^{2}$ Psychiatry, and ${ }^{3}$ Psychology, University of Pittsburgh, Pittsburgh, Pennsylvania 15260
}

\begin{abstract}
The neuropeptide corticotropin-releasing hormone (CRH) activates locus ceruleus (LC) neurons, thereby increasing norepinephrine levels throughout the CNS. Despite anatomical and physiological evidence for CRH innervation of the LC, the mechanism of CRH-evoked activation of $\mathrm{LC}$ neurons is unknown. Moreover, given the apparent absence of mRNA for $\mathrm{CRH}$ receptors in LC neurons, the exact location of action of $\mathrm{CRH}$ within the cerulear region is debated. Using in vitro intracellular recordings from rat brainstem, we examined whether $\mathrm{CRH}$ exerts a direct effect on $\mathrm{LC}$ neurons and which ionic currents are likely affected by $\mathrm{CRH}$. We demonstrate that CRH dose-dependently increases the firing rate of LC neurons through a direct (TTX- and cadmium-insensitive) mechanism by decreasing a potassium conductance. The CRH-evoked activation of $\mathrm{LC}$ neurons is, at least in part, mediated by $\mathrm{CRH}_{1}$ receptors and a cAMP-dependent second messenger system. These data provide additional support that CRH functions as an excitatory neurotransmitter in the LC and the hypothesis that dysfunction of the $\mathrm{CRH}$ peptidergic and noradrenergic systems observed in patients with mood and anxiety disorders are functionally related.
\end{abstract}

Key words: cathecholamine; ceruleus; corticotropin; CRF; intracellular; norepinephrine (noradrenaline)

\section{Introduction}

Since the discovery of corticotropin-releasing hormone (CRH) as a primary initiator for ACTH release from corticotropes (Vale et al., 1981), CRH has been localized at many extra-hypothalamic sites (Swanson et al., 1983; Potter et al., 1994), where it plays an important role in the behavioral response to stress (Dunn and Berridge, 1990; Owens and Nemeroff, 1991; Valentino et al., 1993). The major source of norepinephrine (NE) in the CNS, the locus ceruleus (LC), receives CRH afferents from the brainstem nuclei paragigantocellularis, prepositus hypoglossi, and Barrington's and the central nucleus of the amygdala and the paraventricular nucleus of the hypothalamus (Valentino et al., 1992; Van Bockstaele et al., 1999). Some CRH afferents preferentially target the LC proper, whereas others target the rostromedial and dorsolateral pericerulear regions (Van Bockstaele et al., 2001). Furthermore, CRH terminals contact LC dendrites and presynaptic terminals, thereby providing a neuroanatomical substrate for interaction between CRH and noradrenergic activity throughout the entire forebrain (Van Bockstaele et al., 1999).

CRH administered intraventricularly or locally into the LC increases the LC firing rate (FR) and NE release in its terminal

Received July 14, 2004; revised Aug. 27, 2004; accepted Sept. 8, 2004.

This work was supported by United States Public Health Service Grant DA15408. We thank Niki Macmurdo and Christy Smolak for technical assistance and Brian Lowry for Neuroscope data analysis software. We also thank Dr. Jean Rivier (Clayton Foundation Laboratories for Peptide Biology, Salk Institute, La Jolla, CA) for a very generous contribution of CRH and Pfizer for the gift of CP154,526.

Correspondence should be addressed to Dr. Hank P. Jedema, Department of Neuroscience, University of Pittsburgh, 446 Crawford Hall, Pittsburgh, PA 15260. E-mail: Jedema@bns.pitt.edu.

DOI:10.1523/JNEUROSCI.2830-04.2004

Copyright $\odot 2004$ Society for Neuroscience $\quad 0270-6474 / 04 / 249703-11 \$ 15.00 / 0$ fields (Valentino et al., 1983; Smagin et al., 1995; Finlay et al., 1997; Jedema et al., 2001). CRH immunoreactivity in the LC is increased by cold exposure (Chappell et al., 1986), and CRH is functionally important for LC activation during exposure to several stressors (cold, hypovolemia, and immobilization) (Melia and Duman, 1991; Valentino et al., 1991; Smagin et al., 1997).

CRH receptors have been demonstrated in the LC (Millan et al., 1986; Primus et al., 1997; Sanchez et al., 1999). CRH receptors are divided in two main classes (Hauger et al., 2003b; Bale and Vale, 2004), and at least some receptors in the $\mathrm{LC}$ are of the $\mathrm{CRH}_{1}$ receptor subtype (Sauvage and Steckler, 2001). Recent ultrastructural evidence for $\mathrm{CRH}_{1}$ receptors on $\mathrm{LC}$ neurons has also been reported (Fox et al., 2002; Xu et al., 2004). CRH receptor mRNA has been detected in LC neurons of primates (Sanchez et al., 1999). However, with one exception (Zeng et al., 2003), CRH receptor mRNA has been difficult to detect in the LC of rodents (Potter et al., 1994; Chalmers et al., 1995; Van Pett et al., 2000), leading some to hypothesize a preferential presynaptic neuromodulatory role for $\mathrm{CRH}$ in the LC.

In addition to its site of action, the mechanism underlying the CRH activation of LC neurons is unknown. Typically, CRH receptors are coupled to G-proteins $\left(\mathrm{G}_{\mathrm{S}}\right)$ and activate adenylate cyclase (Bale and Vale, 2004), although coupling to additional G-proteins and second messenger cascades has been reported (Grammatopoulos et al., 2001; Dautzenberg and Hauger, 2002; Blank et al., 2003). In the hippocampus, CRH inhibits a calciumactivated potassium current $\left[I_{\mathrm{K}(\mathrm{Ca})}\right]$ (Aldenhoff et al., 1983), whereas in the amygdala $\mathrm{CRH}$ activates a calcium current $\left(I_{\mathrm{Ca}}\right)$ and inhibits $I_{\mathrm{K}(\mathrm{Ca})}$ (Rainnie et al., 1992; Yu and Shinnick- 
Gallagher, 1998). In corticotropes, $\mathrm{CRH}$ activates $I_{\mathrm{Ca}}$ and a hyperpolarization-activated current $\left(I_{\mathrm{H}}\right)$ and inhibits an inwardrectifying current $\left[I_{\mathrm{K}(\mathrm{IR})}\right]$ (Kuryshev et al., 1996a,b, 1997).

In the present studies, we have characterized the effect of application of $\mathrm{CRH}$ on the electrophysiological activity of LC neurons in horizontal brainstem slices of rats using in vitro intracellular recording techniques.

\section{Materials and Methods}

Animals. Male Sprague Dawley rats (Hilltop, Scottdale, PA) were housed singly in hanging stainless steel cages in a colony room maintained at an ambient temperature of $23^{\circ} \mathrm{C}$. Lights were maintained on a $12 \mathrm{hr}$ light/ dark cycle (lights on at 8:00 A.M.), with food (laboratory rodent diet 5001; PMI Feeds, St. Louis, MO) and water available ad libitum. All protocols were approved by the Institutional Animal Care and Use Committee at the University of Pittsburgh and were handled in accordance with the United States Public Health Service Guide for the Care and Use of Laboratory Animals.

Tissue preparation. Rats (180-300 gm) were anesthetized with chloral hydrate ( $400 \mathrm{mg} / \mathrm{kg}$, i.p.) and perfused through the ascending aorta with an ice-cold, oxygenated (low $\mathrm{Na}$ /high sucrose) perfusion solution (in mм: $1.9 \mathrm{KCl}, 1.2 \mathrm{Na}_{2} \mathrm{HPO}_{4}, 6 \mathrm{MgCl}_{2}, 33 \mathrm{NaHCO}_{3}, 20$ glucose, and 229 sucrose saturated with $95 \% \mathrm{O}_{2} / 5 \% \mathrm{CO}_{2}$ ) (Aghajanian and Rasmussen, 1989). After decapitation, the brain was removed rapidly, placed in cold perfusion solution, and 300- $\mu$ m-thick horizontal slices containing the LC were prepared using a DSK Microslicer (Ted Pella, Redding, CA). Tissue was transferred to cold, oxygenated artificial CSF (aCSF; in mM: $124 \mathrm{NaCl}, 5 \mathrm{KCl}, 1.2 \mathrm{KH}_{2} \mathrm{PO}_{4}, 2.4 \mathrm{CaCl}_{2}, 1.3 \mathrm{MgSO}_{4}, 26 \mathrm{NaHCO}_{3}$, and 10 glucose saturated with $95 \% \mathrm{O}_{2} / 5 \% \mathrm{CO}_{2}$ ). After a recovery period of a minimum of $60-90 \mathrm{~min}$, sections were transferred to a temperaturecontrolled recording chamber (RC-22C; Warner Instruments, Hamden, $\mathrm{CT}$ ) where they were superfused with oxygenated aCSF at a flow rate of $0.8-1.5 \mathrm{ml} / \mathrm{min}$ at $35^{\circ} \mathrm{C}$.

Electrophysiology. Intracellular recordings were obtained from neurons in the LC that were initially identified by their location within the trans-illuminated slice. Electrodes were filled with biocytin (2\% biocytin in 2-3 $\mathrm{M} \mathrm{KC}_{2} \mathrm{H}_{3} \mathrm{O}_{2}, \mathrm{KCl}$, or $\mathrm{CsC}_{2} \mathrm{H}_{3} \mathrm{O}_{2}$ ) and had an impedance of $\sim 50-$ $100 \mathrm{M} \Omega$. Putative LC neurons were identified based on a regular pattern of low-frequency discharge of long duration action potentials, as described in previous studies (Andrade et al., 1983; Williams et al., 1984; Ivanov and Aston-Jones, 1995), and had a minimal spike amplitude of 65 $\mathrm{mV}$. Electrodes were connected to the headstage (HS-2A) of an Axoclamp-2A amplifier (Axon Instruments, Union City, CA) in currentclamp mode. The output of the amplifier was displayed and analyzed using an analog-to-digital board (Microstar Labs, Bellevue, WA) and customized data analysis software (Neuroscope). After determination of basal activity for 3-10 $\mathrm{min}, \mathrm{CRH}$ ( $1 \mathrm{ng} / \mathrm{nl}$ solution) was locally applied by pressure ejection using a Picospritzer II (General Valve, Parker Hannifin, Fairfield, NJ) from a calibrated glass pipette positioned in the bath above the slice (tip size, $10-20 \mu \mathrm{m}$ inner diameter; $\sim 400-600 \mu \mathrm{m}$ from recording site; ejection pressure, $50-75 \mathrm{psi}$ ). Pipettes were calibrated at the end of each experiment by measuring the distance the meniscus moved after ejection of $\sim 50$ pulses of a duration used during the experiment, and the ejection volume was calculated. For each neuron, multiple doses of $\mathrm{CRH}$ (average ejected volume, $143 \mathrm{nl}$ per ejection per neuron) were administered to determine the sensitivity of the neuron to $\mathrm{CRH}$, which appeared to be a function of the responsivity of the individual neuron tested and extrinsic factors such as the proximity of the CRH pipette to the neuron and the fluid level in the recording chamber.

Drugs. Rat/human CRH obtained from Research Biochemicals (Natick, MA) or Bachem (Torrance, CA) was dissolved to a concentration of $1 \mu \mathrm{g} / \mu \mathrm{l}$ in $(\sim 90 \mu \mathrm{l})$ aCSF containing $0.1 \%$ bovine serum albumin and $0.3 \mathrm{~mm}$ ascorbate. Additional rat/human CRH received as a gift from Dr. J. Rivier (Clayton Foundation Laboratories for Peptide Biology, Salk Institute, La Jolla, CA) was dissolved in the same manner. In general, it was necessary to acidify the solution using $1 \mu \mathrm{l}$ of a $30 \%$ acetic acid solution. D-Phe-CRH (12-41) and $\alpha$-helical CRH were obtained from Bachem. A $1 \mu \mathrm{g} / \mu \mathrm{l}$ stock solution of antagonist was prepared in aCSF

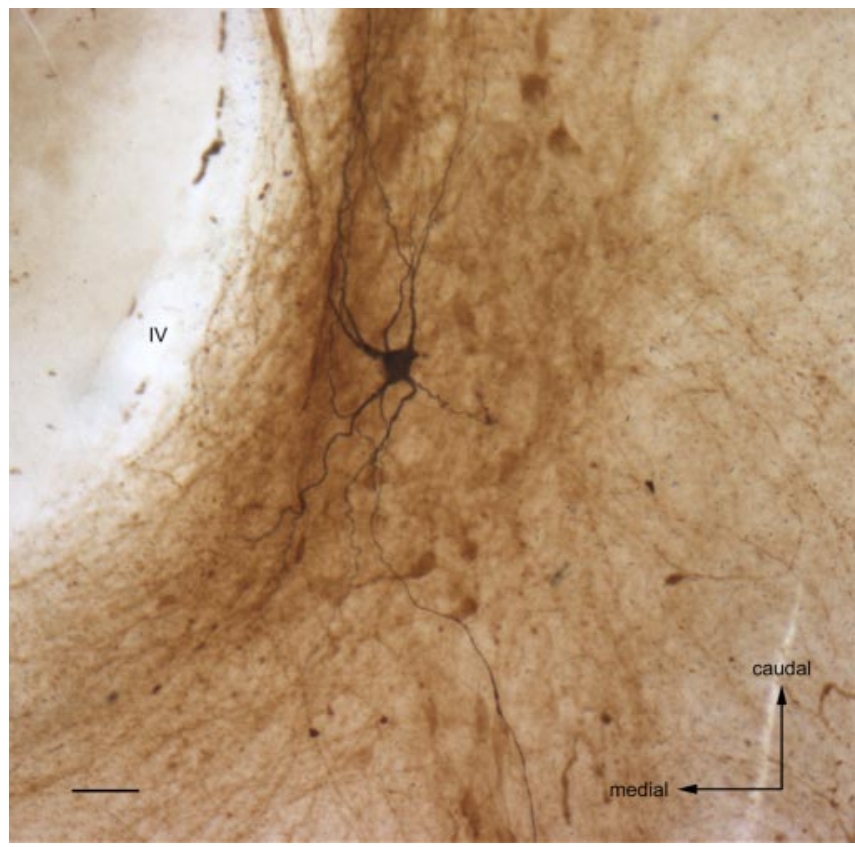

Figure 1. Identification and morphology of $\mathrm{LC}$ neurons. $\mathrm{An} \mathrm{LC}$ neuron stained with biocytin (black) after intracellular recording in a $300-\mu \mathrm{m}$-thick horizontal slice of the rat brainstem is shown. Immunoreactivity for TH (brown) in somata of surrounding neurons outlines the LC. Immunoreactive processes illustrate the preservation of the extensive arborization of $\mathrm{LC}$ neurons outside the nucleus proper, which is where the majority of CRH innervation occurs. Scale bar, $50 \mu \mathrm{m}$. IV, Fourth ventricle.

containing $0.1 \%$ bovine serum albumin and $0.3 \mathrm{~mm}$ ascorbate. The solution was acidified using $1 \mu \mathrm{l}$ of a $30 \%$ acetic acid solution per $100 \mu \mathrm{l}$ of aCSF. For experiments with bath application of antagonists, the stock solution was further diluted to a final concentration with aCSF. To determine the effect of the antagonist, the effect of CRH was determined before and (at least $5 \mathrm{~min}$ ) after bath application of the antagonist. In experiments using local antagonist administration, the stock solution of antagonist $(1 \mu \mathrm{g} / \mu \mathrm{l})$ was administered from a separate pipette via a second Picospritzer starting 1-10 sec before CRH administration. CP154,526, a CRH1-specific antagonist, was a gift from Pfizer (Groton, CT). A stock solution of CP154,526 was made by dissolving the compound in either $0.1 \mathrm{M} \mathrm{HCl}$ or in aCSF containing $10 \%$ DMSO. The stock solution was subsequently diluted to a final concentration using aCSF. The final DMSO concentration in the buffer was $\leq 0.1 \%$. Apamin was obtained from Calbiochem (La Jolla, CA). Tetrodotoxin (TTX) and all other compounds were obtained from Sigma (St. Louis, MO). All drugs were dissolved in aCSF and bath applied at the concentration mentioned, with the exception of potassium chloride, cesium acetate, and the protein kinase A (PKA) inhibitors Rp-cAMP-S and H89 (Calbiochem, San Diego, CA), which were applied intracellularly via the recording electrode. The exchange from aCSF to drug-containing aCSF was achieved using a switch valve (UpChurch Scientific, Oak Harbor, WA). After switchover, it required $\sim 45 \mathrm{sec}$ for the drug-containing solution to reach the recording chamber and 2-3 min before stabilization of the drug effect.

Biocytin was injected into the recorded cell for histological verification. The activity and responsiveness was determined in only one neuron per slice.

Immunocytochemistry. The location of the recorded neurons was verified microscopically to be within the LC (Fig. 1), and as can be seen from the image, the use of horizontally cut sections allowed the preservation of a large part of the extensive dendritic arborization of LC neurons (Travagli et al., 1996) outside the LC proper, which included areas where the majority of CRH innervation is known to occur (Van Bockstaele et al., 2001). Immunocytochemical processing for TH and biocytin was performed as described previously (Jedema and Grace, 2003). Briefly, tissue sections were postfixed in $4 \%$ paraformaldehyde or $10 \%$ buffered forma- 


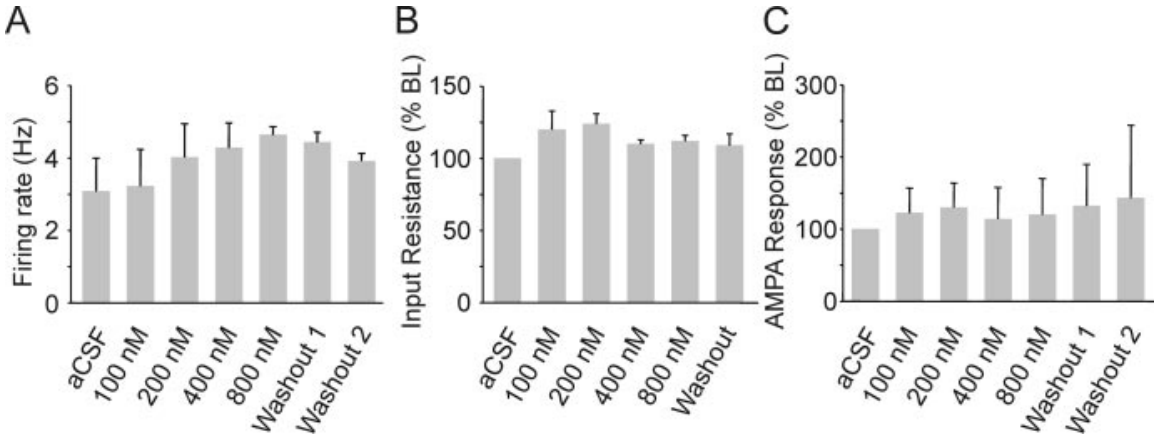

Figure 2. Bath application of $C R H$. $A$, Increasing concentrations of $C R H$ increase the spontaneous discharge rate of $L C$ neurons (maximal increase, $1.5 \pm 0.9 \mathrm{~Hz}$ evoked by an average concentration of $325 \pm 207 \mathrm{~nm} ; n=4$ neurons). The increase in the discharge rate was variable, difficult to quantify, and required an extended period of time to wash out. $B$, Bath application of $C R H$ increases in the input resistance of $\mathrm{LC}$ neurons from an average of $64 \pm 5$ to $82 \pm 10 \mathrm{M} \Omega$ at an average concentration of $375 \pm$ $179 \mathrm{~nm}$ CRH ( $n=4$ neurons). $C$, The response to local administration of AMPA was not reliably altered by bath application of CRH. Measurements for "Washouts 1 and 2" were made between 3 and 7 min and 15 and 30 min after switchover to aCSF, respectively.

lin solution, and after a freeze-thaw procedure and overnight incubation in a $1 \%$ Triton $\mathrm{X}-100$ solution, they were incubated in avidin-biotin peroxidase complex (ABC; 1:200; Vectastain Elite kit; Vector Laboratories, Burlingame, CA). The peroxidase reaction product was subsequently visualized by incubating the sections in $0.022 \%$ diaminobenzidine, $0.3 \% \mathrm{NiSO}_{4}\left(\mathrm{NH}_{4}\right)_{2} \mathrm{SO}_{4}$, and $0.003 \%$ hydrogen peroxide for 6-7 $\mathrm{min}$. Then, after incubation in blocking solution containing 3\% normal goat serum, $0.4 \%$ Triton $\mathrm{X}-100$, and $1 \%$ bovine serum albumin, sections were incubated overnight in blocking solution containing a monoclonal antibody raised in mouse against TH $(1: 10,000$; Chemicon, Temecula, CA), followed by incubation in secondary antibody (BA2001; 1:200; Vector Laboratories), which was then visualized using an $\mathrm{ABC}$ and a peroxidase reaction.

Data analysis. The membrane potential was defined as the change in the electrode potential after withdrawal of the electrode from the membrane. Action potential threshold was defined as the potential at which the greatest change in slope of the membrane potential occurred, which was determined from the second-order derivative of the membrane potential waveform. The amplitude of the action potential and afterhyperpolarization (AHP) were measured relative to this threshold, and the action potential duration was measured at the level of threshold. To determine the effect of $\mathrm{CRH}$ on the action potential waveform, the characteristics of all action potentials occurring during a $5 \mathrm{sec}$ window around the time point of maximal CRH-evoked activation were averaged for each neuron and compared with the average of the same number of action potentials occurring immediately before $\mathrm{CRH}$ administration using paired $t$ tests. The FR was calculated as the sliding average of the number of spikes per second occurring during a $10 \mathrm{sec}$ window starting 4 sec before and ending $5 \mathrm{sec}$ after the $1 \mathrm{sec}$ bin for which it was calculated (Jedema et al., 2001). CRH-evoked increases in the FR were expressed as the maximal increase in the FR above baseline within $30 \mathrm{sec}$ after $\mathrm{CRH}$ administration. We observed that this increase in the FR above baseline was fairly constant and independent of the basal FR as tested by alteration of the FR using hyperpolarizing and depolarizing current injection. The effect of application CRH antagonists or channel blockers such as TTX, apamin, $\mathrm{BaCl}_{2}$, or $\mathrm{CdCl}_{2}$ is compared with the $\mathrm{CRH}$-evoked effect in that neuron under non-drug conditions. The average of the CRH effect before drug application and, whenever possible, after drug washout was used to calculate the reported discharge rate and action potential characteristics under control conditions. $\mathrm{CRH}$-evoked depolarization was measured as the maximal change in membrane potential within $60 \mathrm{sec}$ after $\mathrm{CRH}$ administration. The reversal potential of the CRH-evoked depolarization for each neuron was estimated by linear regression of the relationship between the maximal CRH-evoked depolarization versus membrane potential. The average basal activity calculated for the LC neurons in the present study includes the basal activity of some control LC neurons reported previously (Jedema and Grace, 2003).

\section{Results \\ Basal activity of LC neurons}

The vast majority of LC neurons recorded in vitro with potassium acetate-filled electrodes exhibited spontaneous spike firing (55 of 59), with an average basal FR of $2.2 \pm 0.2 \mathrm{~Hz}$. Using hyperpolarizing current steps (0.1-1.5 $\mathrm{nA}, 200 \mathrm{msec})$ injected through the recording electrode, the input resistance obtained from the slope of the current-voltage plot at the origin ( $y$ intercept of the derivative of the quadratic function describing the $I V$ plot) averaged $80 \pm 5 \mathrm{M} \Omega(n=24)$.

\section{Effect of bath application of $\mathrm{CRH}$}

Bath application of 100, 200, 400, and 800 nM CRH increased the spontaneous FR of LC neurons, but the effect was highly variable and difficult to quantify reliably over the prolonged periods of time necessary to obtain a full dose-response curve. The maximum average increase in the discharge rate was $1.5 \pm 0.9 \mathrm{~Hz}$, which was achieved at an average dose of $325 \pm 207 \mathrm{~nm}(n=4$ neurons) (Fig. 2$)$. The input resistance was increased by bath application of $\mathrm{CRH}$ with a maximal increase of $31 \pm 10 \%$, which occurred at an average dose of $375 \pm 179 \mathrm{~nm} \mathrm{CRH}$. The response to local administration of AMPA via pressure ejection was not reliably altered by bath application of CRH. The increase in the discharge rate of LC neurons did not return to baseline within prolonged washout periods (20-30 $\mathrm{min}$ ). Because of the variability of the results, the high expense associated with bath application of $\mathrm{CRH}$, and the risks of adsorption of neuropeptide to the plastic tubing and desensitization/tachyphylaxis of the response with continuous application (Hauger et al., 2003a), we examined the effects of $\mathrm{CRH}$ applied locally to the neuron via a (post) calibrated micropipette with pressure ejection.

\section{Effect of locally administered CRH on spontaneous activity} Administration of CRH (average dose, $143 \pm 15 \mathrm{ng}$; average dose range, 69-236 ng) by pressure ejection transiently increased the FR of 51 of 53 neurons (Fig. 3). The increase was dose dependent with an average increase of $0.7 \pm 0.1 \mathrm{~Hz}$ occurring $\sim 13 \pm 1 \mathrm{sec}$ after ejection of $\mathrm{CRH}$ from the pipette, and the $\mathrm{CRH}$-evoked activation subsided by $90-120 \mathrm{sec}$ after the termination of the $\mathrm{CRH}$ ejection. LC neurons showed little, if any, short-term desensitization in their response when pulses of CRH were administered repeatedly at $\sim 3$ min intervals. Similar results were obtained when the recording electrodes were filled with potassium chloride, suggesting that chloride conductances are unlikely to be involved in the effect of CRH on LC neurons. These findings are consistent with the existing evidence of an excitatory effect of CRH on LC neurons observed in vivo (Valentino et al., 1983, 1991, 1993; Conti and Foote, 1995; Curtis et al., 1997; Pavcovich and Valentino, 1997; Jedema et al., 2001). The concentration at the receptor site is difficult to estimate when $\mathrm{CRH}$ is applied via pressure ejection, particularly because the drug is washed out rapidly by fresh buffer entering the recording chamber. Based on an average volume of $143 \mathrm{nl}$ per $\mathrm{CRH}$ administration applied over $1040 \mathrm{msec}$, one would estimate a $>1000$-fold dilution in the recording chamber $(200 \mu \mathrm{l})$, resulting in an estimated CRH concentration of $\sim 150 \mathrm{~nm}$. This is within the range of concentrations used in our experiments with bath application of $\mathrm{CRH}$ described 
A

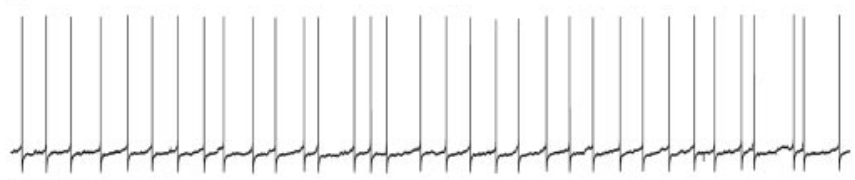

$0.85 \mathrm{~Hz}$

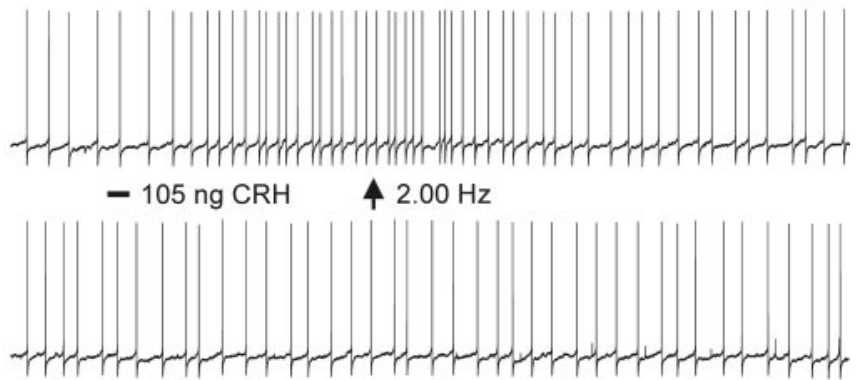

B

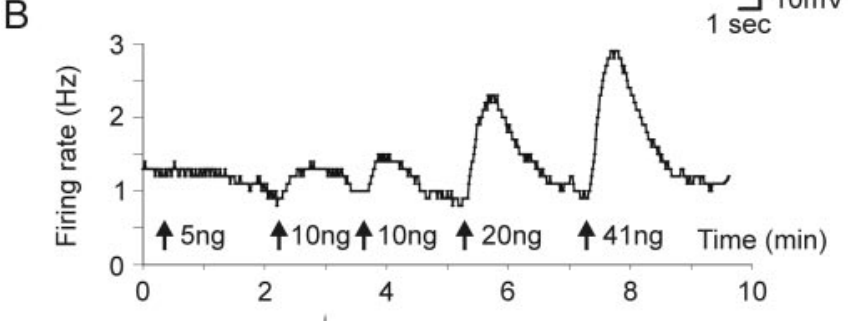

C

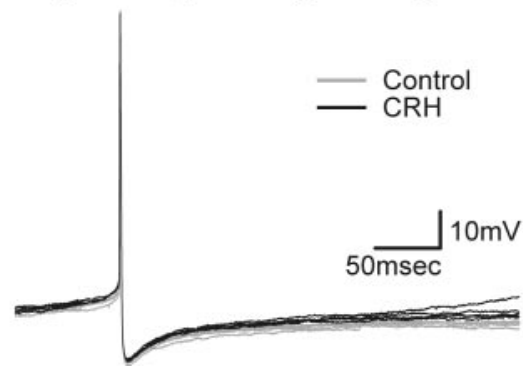

Figure 3. Local administration of $C R H$ increases the FR of spontaneously active $L C$ neurons by increasing the rate of repolarization. $A$, The average baseline FR of this spontaneously active LC neuron was $0.85 \mathrm{~Hz}$. CRH (105 ng) was ejected (horizontal bar) in the bath $\sim 400 \mu \mathrm{m}$ from the recording site. A maximum FR of $2.00 \mathrm{~Hz}$ was reached at $12 \mathrm{sec}$ (arrow) after CRH ejection. $B$, Repeated CRH administration causes an increase in the FR that is transient and dose dependent. The maximal activation in this $L C$ neuron occurs $\sim 15 \mathrm{sec}$ after CRH ejection, and the FR has returned to baseline levels within $90-120 \mathrm{sec}$. C, An overlay of five action potential waveforms at the time point of maximal CRH-evoked activation (black) demonstrates that the waveform is similar to the waveform of five action potentials from the same neuron immediately before CRH ejection (gray). At the time of maximal CRH-evoked activation, the rate of repolarization after action potential discharge is faster, leading to a more rapid return to action potential threshold and consequently an increase in the FR of the neuron.

above. In addition, in previous studies, 15-500 nM CRH has been used for electrophysiological experiments on corticotropes (Kuryshev et al., 1996a,b, 1997) and neurons in the amygdala and hippocampus (Aldenhoff et al., 1983; Siggins et al., 1985; Aldenhoff, 1986; Rainnie et al., 1992; Yu and Shinnick-Gallagher, 1998). In studies on an LC-like cell line (CATHa), $500 \mathrm{~nm} \mathrm{CRH}$ was necessary to achieve a maximal effect on neurite outgrowth and cAMP accumulation (Bundey and Kendall, 1999; Thiel and Cibelli, 1999; Cibelli et al., 2001).

Effect of CRH on action potential characteristics

There was no difference in the action potential waveform of LC neurons recorded immediately before and at the point of maximal CRH-evoked activation (Table 1). However, the rate of repolarization of the membrane potential after action potential dis-
Table 1. Action potential characteristics

\begin{tabular}{lcr}
\hline & \multicolumn{1}{c}{ Control } & \multicolumn{1}{c}{ CRH } \\
\hline Threshold (in millivolts) & $-45.9 \pm 2.1$ & $-45.7 \pm 2.1$ \\
Amplitude (in millivolts) & $71.7 \pm 1.2$ & $71.3 \pm 1.2$ \\
Duration (in milliseconds) & $2.0 \pm 0.1$ & $2.0 \pm 0.1$ \\
AHP (in millivolts) & $20.4 \pm 0.5$ & $20.3 \pm 0.6$ \\
Interspike interval (in milliseconds) & $585 \pm 114$ & ${ }^{a} 421 \pm 84$ \\
Rate of repolarization (in millivolts & $55 \pm 7$ & ${ }^{a} 74 \pm 9$ \\
$\quad$ per second) & & \\
\hline
\end{tabular}

Data show the characteristics of spontaneously occurring action potentials recorded during a 5 sec epoch of maxima CRH-evoked activation compared with the same number of action potentials recorded immediately before CRH administration ( 2 pulses for each neuron) in $10 \mathrm{LC}$ neurons.

${ }^{a} p<0.05$.

charge was faster after CRH administration, resulting in a more rapid depolarization to spike threshold (Table 1, Fig. 3). Given that $\mathrm{CRH}$ increases the LC FR, it was indeed expected that $\mathrm{CRH}$ affects conductances that are active during the period between action potentials rather than conductances that are selectively active during action potential discharge.

\section{Effect of CRH after blockade of synaptic activity}

When synaptic activity in the slice was prevented by bath application of $2 \mu \mathrm{M}$ TTX, the spontaneous discharge of action potentials was altered, and the neurons began the discharge of putative calcium spikes (Williams et al., 1984). In most cases (four of six), the neurons would cease their spontaneous activity, although calcium spike discharge activity could be reinstated by injecting a small amount of depolarizing current into the neuron (20-250 pA). In two cases, these calcium spikes continued to occur spontaneously. Administration of CRH (at the same doses as before TTX) caused a transient increase in calcium spike activity with a similar time course as in the same cell tested before TTX perfusion. This was observed in six of six LC neurons (Fig. 4). The fact that the increase in the FR persisted after blockade of synaptic activity by TTX demonstrates that the effect of $\mathrm{CRH}$ in vitro is primarily mediated via a direct action on LC neurons and that fast sodium currents are likely not to be a major contributor to the excitatory effect of CRH.

When calcium-dependent transmitter release in the slice was prevented by bath application of $\mathrm{CdCl}_{2}(100 \mu \mathrm{M})$, the basal discharge rate of LC neurons increased $(1.73 \pm 0.67 \mathrm{~Hz}$ before and $4.58 \pm 1.50 \mathrm{~Hz}$ after switch to $\left.\mathrm{CdCl}_{2} ; n=4 ; p<0.05\right)$; this was most likely attributable to a blockade of calcium-activated potassium conductances $\left(K_{\mathrm{Ca}}\right)$ (Fig. 5) (Osmanovic and Shefner, 1993). $\mathrm{CRH}$ administration (at the same doses as before $\mathrm{CdCl}_{2}$ ) continued to increase the discharge rate of LC neurons in the presence of $\mathrm{CdCl}_{2}$. The absolute magnitude of the $\mathrm{CRH}$-evoked increase was also higher $(0.50 \pm 0.16 \mathrm{~Hz}$ before and $0.85 \pm 0.21$ $\mathrm{Hz}$ after switch to $\left.\mathrm{CdCl}_{2} ; n=4 ; p<0.01\right)$, but the time course of activation was similar as that observed under control conditions (maximal activation at $15 \pm 2 \mathrm{sec}$ ). These observations again demonstrate that the effect of $\mathrm{CRH}$ in vitro is primarily mediated via a direct action on LC neurons and, moreover, that changes in calcium conductances are likely not to be a major contributor to the excitatory effect of CRH. Consistent with a direct excitatory effect of $\mathrm{CRH}$, no spontaneous postsynaptic potentials were observed in our slices before and during $\mathrm{CRH}$ administration in any experiments.

\section{Effect of CRH on hyperpolarized LC neurons}

When hyperpolarizing current was delivered through the recording electrode to prevent spike discharge, the administration of 


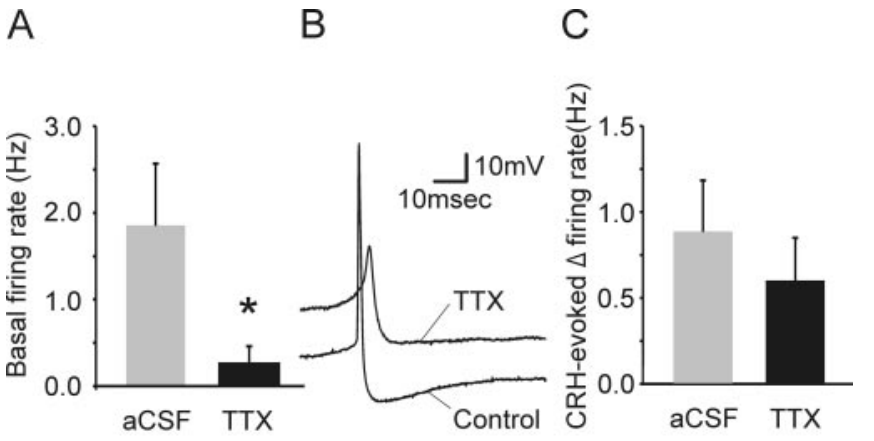

D aCSF

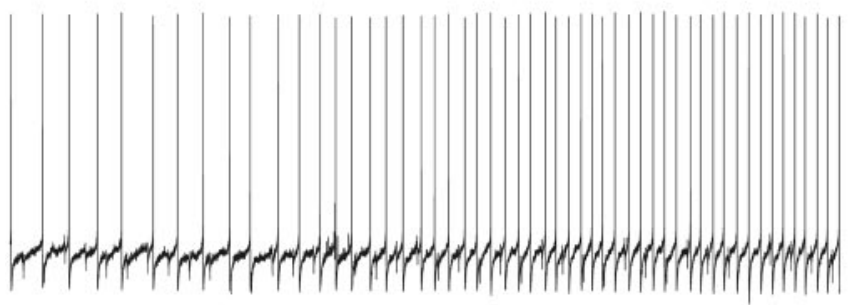

- 36ng CRH

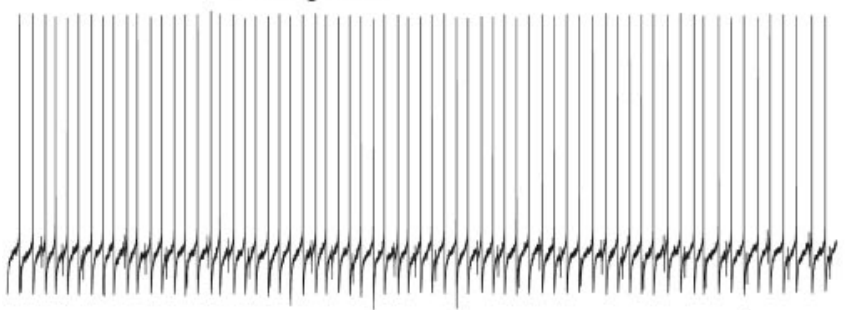

E TTX $(2 \mu \mathrm{M})$

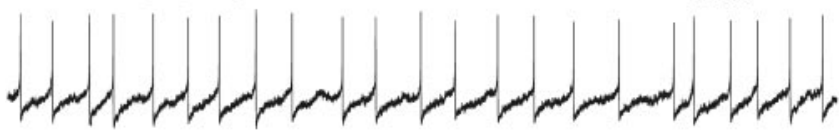

$1.20 \mathrm{~Hz}$

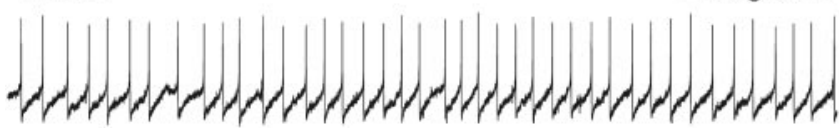

^ $2.20 \mathrm{~Hz}$

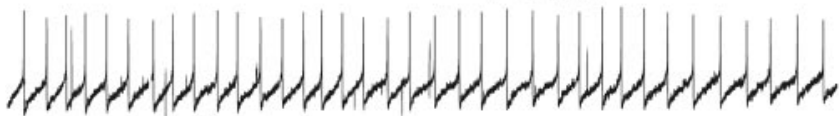

Figure 4. CRH increases the discharge rate of putative calcium spikes in $L C$ neurons in the presence of TTX. A, When synaptic activity is prevented by bath application of TTX $(2 \mu \mathrm{M})$, the basal $F R$ of $\mathrm{LC}$ neurons decreases significantly. $B$, This $\mathrm{LC}$ neuron continued to discharge calcium spikes spontaneously. $C$, In the presence of TTX, CRH increased the calcium spike rate in six of six neurons to a similar extent as before TTX. D, Representative trace demonstrating that CRH administration ( $36 \mathrm{ng}$; horizontal bar) increased the FR of this neuron under control conditions (aCSF). E, In the same neuron, the calcium spike discharge rate after bath application of TTX (2 $\mu \mathrm{M}$ ) was increased from 1.20 to $2.20 \mathrm{~Hz}$ at $16 \mathrm{sec}$ after CRH administration.

CRH caused a transient depolarization (average depolarization, $2.8 \pm 0.4 \mathrm{mV}$ ) with a similar time course as the CRH-evoked increase in the FR (time point of maximal depolarization, $17 \pm 1$ sec after CRH) (Fig. 6). The magnitude of the depolarization was voltage dependent with an extrapolated reversal potential of $-114 \pm 8 \mathrm{mV}(n=21)$. In some experiments $(n=11)$, repeated brief hyperpolarizing current steps (10-20 msec, $100-300$ pA, 1 $\mathrm{Hz}$ ) were applied in addition to the constant hyperpolarizing
A $\quad$ B $\quad$ C

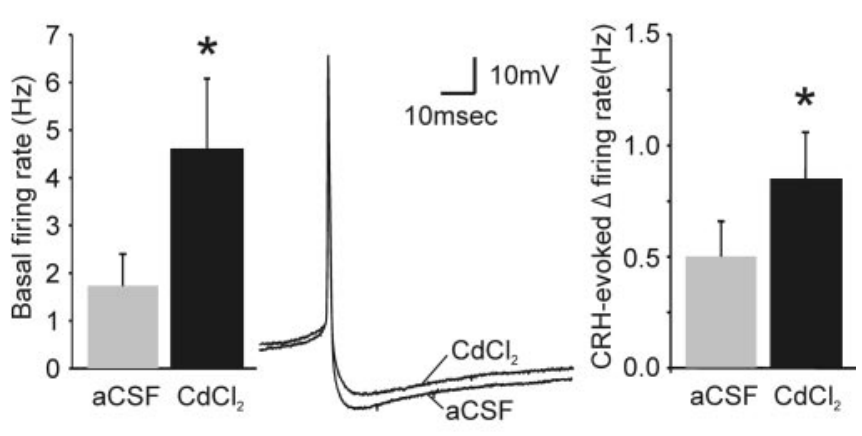

D $\quad \mathrm{CdCl}_{2}(100 \mu \mathrm{M})$

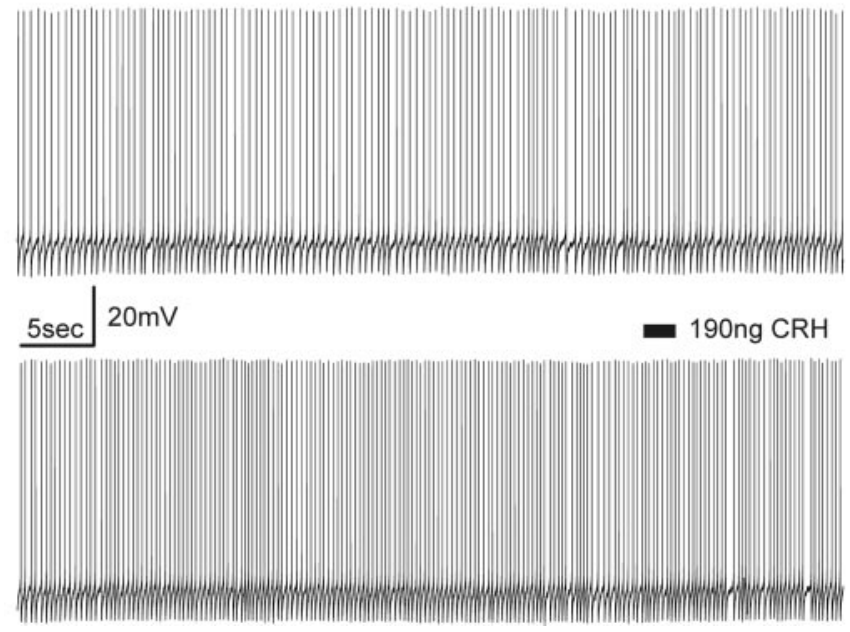

Figure 5. CRH increases the FR of $\mathrm{LC}$ neurons in the presence of cadmium. $A$, When calciumdependent neurotransmitter release is prevented by bath application of the $\mathrm{CdCl}_{2}(100 \mu \mathrm{M})$, the basal FR of $\mathrm{LC}$ neurons increased significantly. $B$, This increase occurs most likely as a result of blockade of calcium-activated potassium conductances, leading to a decreased AHP. C, In the presence of cadmium, CRH administration increases the LC FR to a greater extent $(0.85 \pm 0.21$ vs $0.50 \pm 0.16 \mathrm{~Hz} ; p<0.01$ ), but with a similar time course (maximal activation at $15 \pm 2 \mathrm{sec}$ ) as under control conditions. D, Representative trace demonstrating the CRH-evoked activation in the presence of $\mathrm{CdCl}_{2}$.

current to estimate changes in input resistance. An increase in input resistance was observed to coincide with the $\mathrm{CRH}$-evoked depolarization (average increase, $7 \pm 1 \%$ at $27 \pm 6 \mathrm{msec}$ after CRH ejection; $n=11$ ) (Fig. 6). A depolarization of similar magnitude evoked by reducing the amplitude of constant hyperpolarizing current injected did not change the input resistance estimate (data not shown). The CRH-evoked depolarization also persisted in the presence of TTX ( $n=1$; data not shown).

\section{Attenuation of potassium conductances}

To determine whether the increase in the FR was mediated by a reduction of potassium conductances, potassium conductances were blocked with cesium applied intracellularly. As expected, LC neurons recorded with cesium-containing electrodes (3 M) exhibited a depolarized membrane potential, an increased basal discharge rate and action potential duration, and a reduced AHP (Fig. 7). Only much (approximately threefold) higher doses of $\mathrm{CRH}$ were able to cause an increase in discharge rate, which was significantly reduced compared with control neurons $(0.1 \pm 0.1$ $\mathrm{Hz} ; n=4 ; p<0.01)$. Although the response to $\mathrm{CRH}$ was greatly diminished, the FR of the neuron was increased by bath applica- 
A

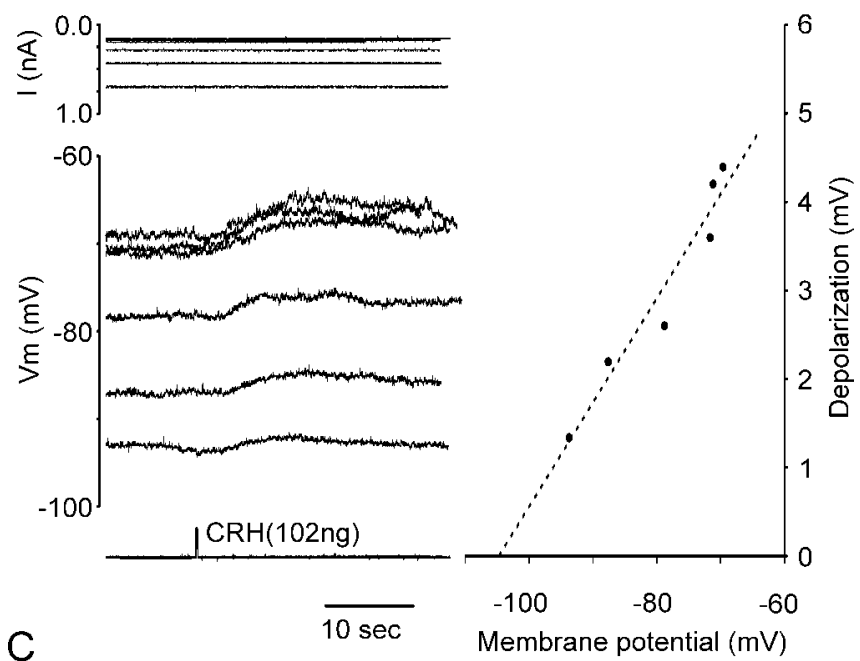

$\mathrm{C}$

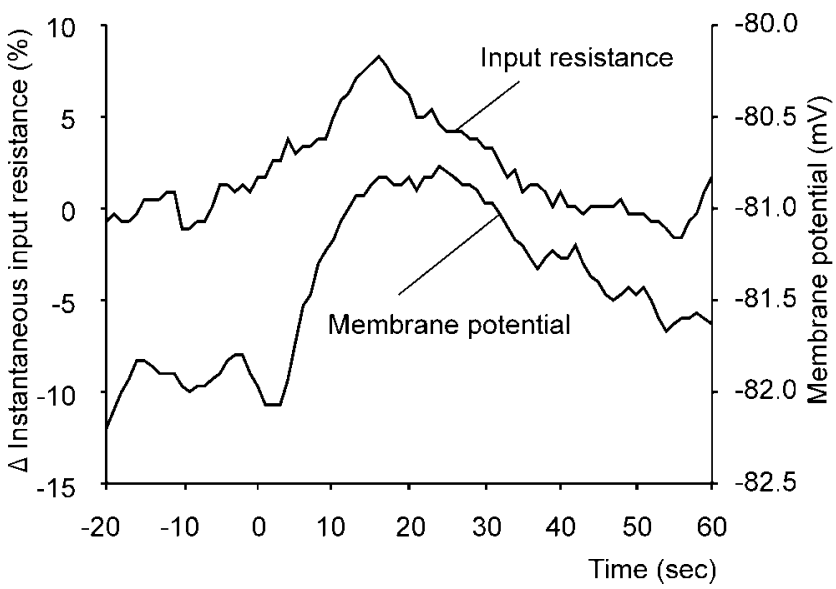

Figure 6. CRH depolarizes the membrane of $\mathrm{LC}$ neurons in the absence of action potential discharge. $A$, When action potential discharge is prevented by constant hyperpolarizing current delivered through the recording electrode, CRH ejection causes depolarization of the membrane potential. $B$, The magnitude of the CRH-evoked voltage deflection is voltage dependent with a reversal potential of $-114 \pm 8 \mathrm{mV}(n=21)$. C, The magnitude of voltage deflections produced in response to repeated hyperpolarizing current steps $(0.3 \mathrm{nA}, 10 \mathrm{msec}, 1 \mathrm{~Hz})$ increases during the $\mathrm{CRH}$-evoked depolarization, indicating an increase in input resistance. Current-evoked depolarization of the same magnitude as that caused by CRH did not change the input resistance (data not shown).

tion of glutamate $(300 \mu \mathrm{M})$. These data demonstrate that the effect of CRH on LC neurons is mediated primarily by a change in potassium conductances.

Given that in the hippocampus and amygdala the effect of $\mathrm{CRH}$ is thought to be mediated by altering $I_{\mathrm{K}(\mathrm{Ca})}$, the effect of bath application of the calcium-activated potassium channel blocker apamin (200 nM) was examined. Apamin caused a small reduction in the amplitude of the AHP; nonetheless, the CRHevoked increase in the FR persisted during bath application of apamin in three of three neurons (Fig. $8 \mathrm{~A}$ ). The effect of blockade of the inward-rectifying potassium conductances $\left[I_{\mathrm{K}(\mathrm{IR})}\right]$ on the $\mathrm{CRH}$-evoked increase in the FR was examined using bath application of $\mathrm{BaCl}_{2}(100 \mu \mathrm{M}) . \mathrm{BaCl}_{2}$ application increased the spontaneous FR of LC neurons in all neurons tested, and the currentvoltage relationship of LC neurons during $\mathrm{Bacl}_{2}$ application was linear, indicating that the $I_{\mathrm{K}(\mathrm{IR})}$ conductances were effectively blocked (Fig. $8 \mathrm{~B}$ ). The $\mathrm{CRH}$-evoked increase in the FR persisted during bath application of $\mathrm{BaCl}_{2}$ in five of five neurons (Fig. $8 \mathrm{~B}$ ).
A

B

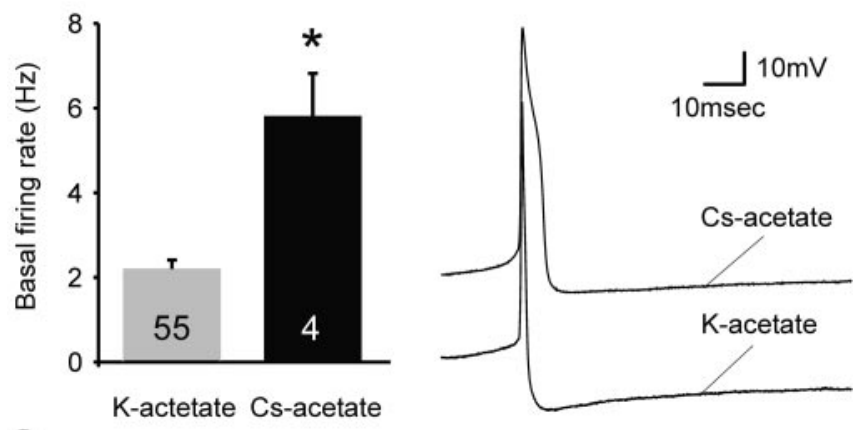

C

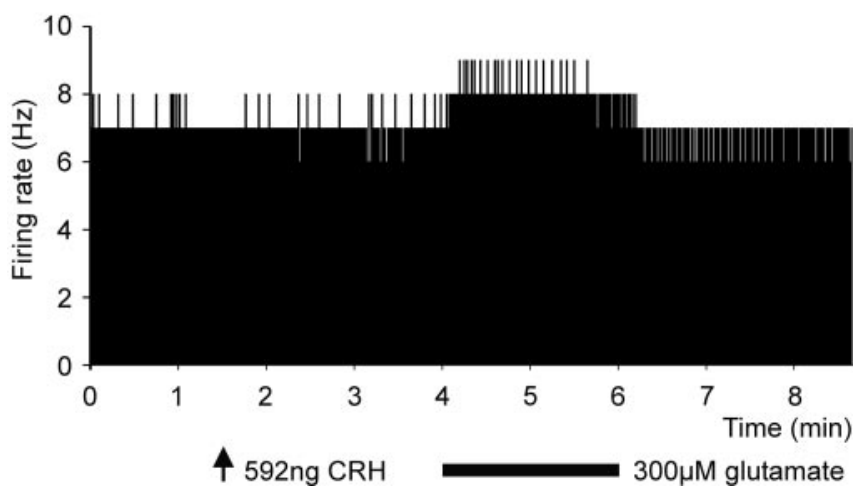

Figure 7. The $\mathrm{CRH}$-evoked increase of $\mathrm{LC}$ neuron activity was reduced when potassium conductances are blocked by cesium. $A, \mathrm{LC}$ neurons recorded with electrodes containing cesium acetate ( $3 \mathrm{~m}$ ) exhibit a higher FR. B, Cesium also caused a depolarized membrane potential, a much longer duration action potential, and a reduced AHP. C, Administration of a higher dose of CRH only causes a slight increase in the FR $(0.2 \mathrm{~Hz})$. Nevertheless, the FR of the neuron was increased by bath application of glutamate $(300 \mu \mathrm{m})$.

\section{Effect of CRH antagonists}

Bath application of the CRH antagonist D-Phe-CRH $(0.1-1 \mu \mathrm{M})$ caused a transient increase in the basal FR in five of seven LC neurons. Nevertheless, the magnitude of the CRH-evoked increase in the FR was reduced to $64 \pm 12 \%$ of control by the administration of D-Phe-CRH (Fig. 9). Local application of D-Phe-CRH via pressure ejection also increased the spontaneous discharge activity. The increase in the FR elicited by local D-Phe$\mathrm{CRH}$ was transient and had a similar time course as the CRHevoked activation (Fig. 9). Vehicle ejections (acidified aCSF with $0.1 \%$ bovine serum albumin and $0.3 \mathrm{~mm}$ ascorbate) did not cause an activation of the LC FR (Fig. 9). Local application of another peptidergic CRH antagonist, $\alpha$-helical CRH, increased the LC discharge rate in a manner similar to D-Phe-CRH. Despite the fact that local administration of $\alpha$-helical CRH increased the basal FR, it reduced the absolute magnitude of the $\mathrm{CRH}$-evoked activation (to $77 \pm 11 \% ; n=3$ ). Bath application of the specific $\mathrm{CRH}_{1}$ receptor antagonist $\mathrm{CP} 154,526(1-100 \mu \mathrm{M})$ reduced the magnitude of the effect of CRH to $66 \pm 13 \%(n=7)$ without alterations of the basal FR (Fig. 9).

\section{Second messenger systems}

LC neurons impaled with sharp electrodes containing the cyclic nucleotide analog and protein kinase A (PKA) inhibitor RpcAMP-S (4.5 mM) exhibited normal electrophysiological characteristics (spike waveform and FR) immediately after penetration by the electrode (Fig. 10). However, after a $\sim 5$ min delay, the 


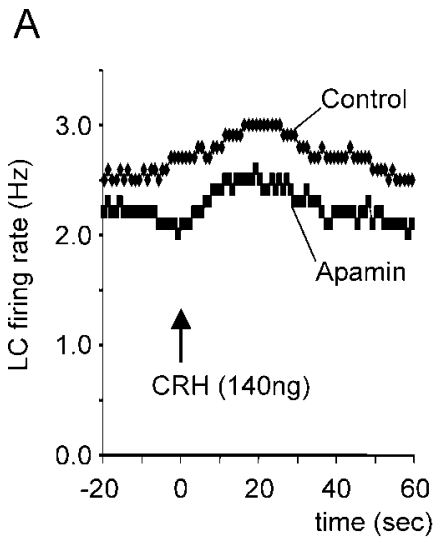

$\mathrm{B}$

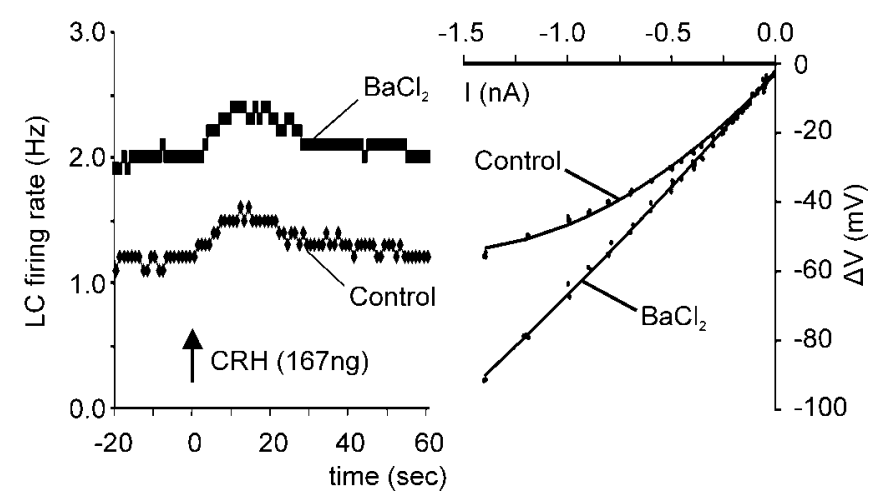

Figure 8. The CRH-evoked increase in the FR persists during blockade of several specific potassium conductances. A, Bath application of a blocker of calcium-activated potassium conductances, apamin (200 nm), does not affect the CRH-evoked increase in the LC FR. The effectiveness of apamin blockade on the AHP is evident in an overlay of the action potential waveform obtained before and during apamin administration. $B$, Bath application of a blocker of inwardly rectifying potassium conductances, $\mathrm{BaCl}_{2}(100 \mu \mathrm{m})$, increases the spontaneous FR of $\mathrm{LC}$ neurons but does not affect the CRH-evoked increase in the LCFR. The effectiveness of barium in blocking inwardly rectifying potassium conductances is evident from a comparison of the current-voltage plots obtained before and during barium administration.

basal FR decreased and eventually ceased. When CRH was applied during the first 5 min after penetration of the neuron, an increase in activity was observed that had a similar time course as that observed in cases in which electrodes without the PKA inhibitor were used. However, at later time points, CRH was unable to increase the activity of the neurons $(1 \pm 2 \% ; n=3)$ even when much higher doses of CRH (up to $1013 \mathrm{ng}$ ) were tested. In experiments using intracellular administration of a different PKA inhibitor, H89 $(10-50 \mu \mathrm{M})$, the baseline FR was also reduced (to $25 \pm 18 \% ; n=4$ ); however, the CRH-evoked responses of LC neurons remained unchanged ( $90 \pm 32 \%$ ), even after prolonged periods ( $>45 \mathrm{~min}$ ) to assure diffusion into the recorded neuron. These data suggest that although both PKA inhibitors decreased the FR of LC neurons, the ability of Rp-cAMP-S to attenuate the response to $\mathrm{CRH}$ was more likely attributable to its CAMP antagonist properties rather than PKA inhibition.

\section{Discussion}

\section{Methodological considerations}

This study used intracellular recordings with sharp electrodes. Although sharp electrodes are unlikely to achieve a good space clamp, space-clamp problems with LC neurons have been reported even in whole-cell recordings, especially when using horizontal slices (Travagli et al., 1996). We used horizontal slices to
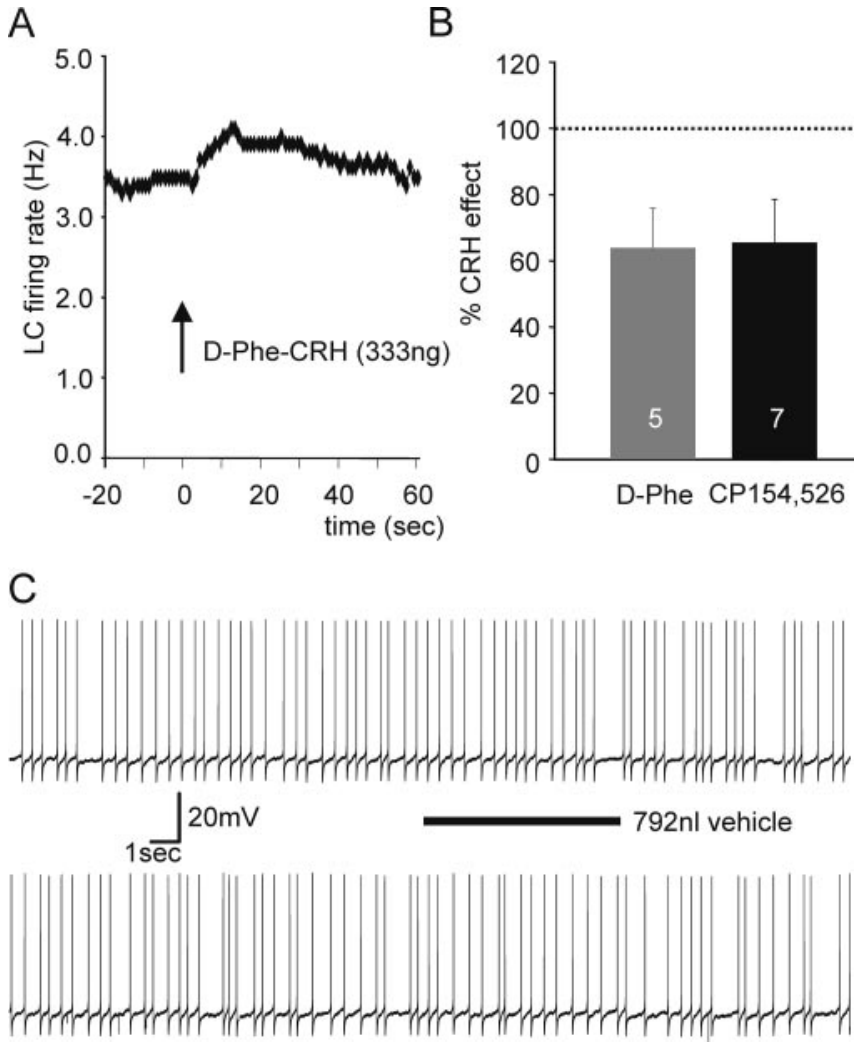

Figure 9. The magnitude of the CRH-evoked increase in the $F R$ was reduced by $C R H$ antagonists. $A$, Local administration ofD-Phe-CRH increases the LCFR with a time course similar to the CRH-evoked activation of $\mathrm{LC}$ neurons. $B$, Although bath application of the CRH antagonist D-Phe-CRH (1 $\mu \mathrm{m})$ also increased the spontaneous FR of $L C$ neurons, it reduced the magnitude of the effect of CRH. Bath application of CP154,526 (1-100 $\mu \mathrm{m})$ reduced the effect of CRH without increasing the basal FR. The numbers on each bar indicate the number of neurons contributing to the average. C, Vehicle ejection (note the large volume) does not affect the LCFR.

preserve the extracerulear dendritic arborizations of LC neurons because the majority of the $\mathrm{CRH}$ innervation of LC neurons occurs in the pericerulear region outside of the nucleus proper (Van Bockstaele et al., 1999). Washout of the intracellular messengers involved in the cAMP cascade has been reported for LC neurons (Alreja and Aghajanian, 1991, 1995). Given the reported role of cAMP for CRH function, we used sharp electrodes to confirm its role in the LC. Bath application is frequently used to permit an estimation of pharmacodynamic parameters of drugs such as $\mathrm{ED}_{50}$ value. However, the response to bath-applied $\mathrm{CRH}$ was difficult to quantify reliably, and we chose to use local administration of CRH to avoid problems with the reported adhesion of neuropeptides to plastics and desensitization of the response to $\mathrm{CRH}$ as a result of the continuous presence of the peptide (Hauger et al., 2003a).

\section{Site of action of CRH on LC neurons}

Valentino and co-workers first demonstrated that CRH increases the LC FR in vivo (Valentino et al., 1983) and hypothesized that $\mathrm{CRH}$ acts within the LC given that intra-LC CRH is more potent than intraventricular $\mathrm{CRH}$ and that the effect of intraventricularadministered $\mathrm{CRH}$ and certain stressors can be blocked by intra-LC infusion of a CRH antagonist (Valentino et al., 1991; Smagin et al., 1995, 1997; Curtis et al., 1997). We demonstrate here that CRH activates LC neurons directly even when synaptic activity is prevented. This direct action is consistent with ultrastructural evidence for synaptic contacts between CRH- 
A Rp-cAMP-S

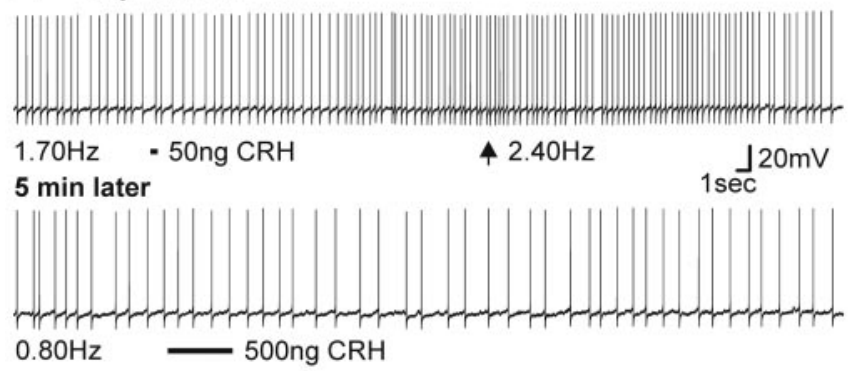

B $\mathrm{H} 89$

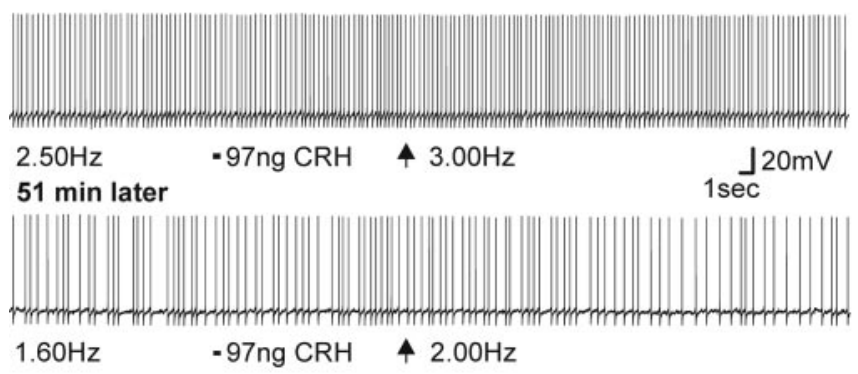

C

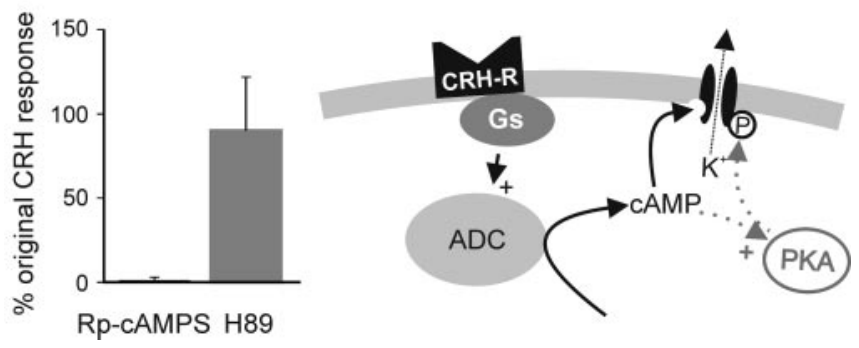

Figure 10. The increase in the $L C$ neuron $F R$ is prevented by intracellular administration of the PKA inhibitor Rp-CAMP-S but not by H89. A, When tested within the first 5 min of impalement of the neuron with an electrode containing the cyclic nucleotide analog and PKA inhibitor Rp-cAMP-S ( $4.5 \mathrm{mm;} \sim 400 \times \mathrm{IC}_{50}$ value), $(\mathrm{RH}$ administration (50 ng) increased the $\mathrm{LC}$ neuron FR. Diffusion of Rp-CAMP-S into the cell decreases the spontaneous FR. Five minutes after the initial activation by $\mathrm{CRH}$, administration of 10 -fold higher doses of $\mathrm{CRH}$ no longer increases the LC FR. $B$, In contrast, LC neurons recorded with electrodes containing the PKA inhibitor H89 (10-50 $\mu \mathrm{m} ; \sim 1000 \times \mathrm{IC}_{50}$ value) exhibit a response to $\mathrm{CRH}$ that is stable over time. $C$, The increase in the LC FR in response to CRH administration at later time points was expressed as a percentage of the response to $\mathrm{CRH}$ immediately after entry of the neuron with electrodes containing Rp-CAMP-S $(n=3)$ or H89 $(n=4)$. D, We interpret these data to indicate that CRH activates $L C$ neurons via a cAMP-dependent mechanism independent of PKA.

immunoreactive terminals and LC dendrites and by the presence of $\mathrm{CRH}_{1}$ receptors on LC neurons (Van Bockstaele et al., 1999; Fox et al., 2002). Our in vitro studies do not, however, rule out the possibility of additional presynaptic actions of $\mathrm{CRH}$ in vivo. Others have argued, based on the slower time course of CRH compared with glutamate, that CRH increases NE efflux through an indirect mechanism (Palamarchouk et al., 2000, 2002). However, based on the caudal injection sites in the LC in their study, CRH would have to diffuse a much greater distance to its receptor given the point of CRH innervation in the pericerulear area (Van Bockstaele et al., 1999); in contrast, infusions of glutamate should act on glutamate receptors located at multiple sites along the dendritic tree (Van Bockstaele and Colago, 1996). Moreover, the faster diffusion characteristics for glutamate based on its lower molecular weight (Nicholson and Tao, 1993) and hydrophilic nature, coupled with its very short extracellular half-life because of an efficient uptake system (Danbolt, 2001), could further contribute to the difference in time course of glutamate- and CRHevoked NE efflux. The fact that in the present experiments the $\mathrm{CRH}$-evoked activation reaches a maximum within $\sim 15 \mathrm{sec}$ after local CRH administration, much faster than the 11-16 min that these authors observed, further suggests that differences in diffusion kinetics underlie the difference in the reported time course of NE efflux.

Potential mechanism of CRH action: potassium conductances The CRH-evoked activation of LC neurons persisted in the presence of TTX and $\mathrm{CdCl}_{2}$ but was prevented by intracellular cesium administration. Moreover, CRH administration depolarized LC neurons when spike discharge was prevented by hyperpolarizing current injection. The reversal potential of the CRH-evoked depolarization was more hyperpolarized than the reversal potential for potassium predicted by the Nernst equation $\left(-88 \mathrm{mV}\right.$ at $35^{\circ} \mathrm{C}$ and $\left[\mathrm{K}^{+}\right]_{\mathrm{o}}=6.2 \mathrm{~mm}$ (Egan et al., 1983) and was accompanied by an increase in input resistance. The combination of an increase in input resistance and a $-115 \mathrm{mV}$ reversal potential suggests that a decrease in potassium conductances mostly mediates the CRHevoked depolarization. The fact that $\mathrm{CRH}$ likely acted on sites electrotonically distal to the soma could account for the more hyperpolarized reversal potential for the $\mathrm{CRH}$-evoked depolarization compared with that for potassium. LC neurons in general and LC neurons in horizontal slices in particular are known not to be electrotonically compact (Travagli et al., 1996). Given that a large part of the CRH innervation of LC neurons occurs in the pericerulear area (i.e., distal to the soma), the reversal potential of a CRH effect measured at the soma likely overestimates the reversal potential of CRH responses at electrotonically distal sites. However, other conductances with a positive reversal potential could contribute to the $\mathrm{CRH}$-evoked depolarization, resulting in a reversal potential more negative than that for potassium (Brown et al., 1971). Thus, the closing of an inward cation conductance in addition to the opening of a potassium conductance has been suggested for the enkephalin- and muscarine-mediated hyperpolarization of LC neurons (Shen and North, 1992a; Alreja and Aghajanian, 1994), whereas the opposite has been suggested for the substance P (SP)-mediated depolarization of LC neurons (Shen and North, 1992b; Koyano et al., 1993). Although in the present experiments the contribution of other conductances to the CRH-evoked depolarization cannot be completely excluded, blockade of fast sodium or calcium conductances did not prevent the CRH-mediated increase in the discharge rate of LC neurons. Therefore, the present data suggest that the majority of the CRHevoked response is mediated by an attenuation of a potassium conductance.

The effect of CRH on LC neurons was not blocked by apamin, a specific blocker for $I_{\mathrm{K}(\mathrm{Ca})}$ that is effective at blocking the intermediate component of the AHP in LC neurons (Osmanovic et al., 1990) and reduced the AHP amplitude in the present experiments. The lack of $I_{\mathrm{K}(\mathrm{Ca})}$ involvement is consistent with the persistence of the excitatory effect of $\mathrm{CRH}$ in the presence of $\mathrm{CdCl}_{2}$ and the depolarizing action of $\mathrm{CRH}$ in hyperpolarized, nondischarging neurons. The blockade of $I_{\mathrm{K}(\mathrm{IR})}$ did not prevent the effect of CRH on LC neurons although barium readily blocked the inward rectification. Collectively, these data suggest that $\mathrm{CRH}$ modulates LC neuron activity via a different potassium conductance than has been suggested for corticotropes and neurons in the hippocampus and amygdala (Siggins et al., 1985; Aldenhoff, 1986; Rainnie et al., 1992; Kuryshev et al., 1997).

Several neurotransmitters modulate potassium conductances 
to affect LC activity. Thus, neuropeptide Y (NPY), galanin, somatostatin, enkephalin, and NE reduce LC activity by increasing an inwardly rectifying potassium conductance (Williams et al., 1985, 1988; Inoue et al., 1988; Illes et al., 1993; Pieribone et al., 1995), whereas hypocretin, SP, and VIP increase LC activity by decreasing a potassium conductance (Wang and Aghajanian, 1990; Koyano et al., 1993; Ivanov and Aston-Jones, 2000). It has been suggested that enkephalin, NE, SP, somatostatin, and NPY affect the same potassium conductance (Aghajanian and Wang, 1987; Illes and Regenold, 1990; Velimirovic et al., 1995). Although the effect of somatostatin and enkephalin can be prevented by bath application of barium, it is possible that CRH may be exerting its primary effect via actions on a similar potassium conductance.

\section{Antagonists of CRH receptors}

The effect of CRH administration was partly blocked by local or bath application of the $\mathrm{CRH}$ receptor antagonist D-Phe-CRH. Because D-Phe-CRH is a competitive antagonist, local application of small volumes of agonist in high concentration may have effectively displaced a sufficient amount of antagonist to elicit some excitatory effect. In contrast, we noted a significant activation of LC neurons by local or bath application of the antagonist alone, with a similar time course of activation as the CRH-evoked activation. Such data are consistent with a partial agonist action of D-Phe-CRH, perhaps similar to the effect of higher concentrations of D-Phe-CRH used for raphe neurons (Kirby et al., 2000) but not in the LC (Curtis et al., 1994, 1999). However, a partial agonist effect of D-Phe-CRH in the LC could potentially be masked by a low baseline $\mathrm{CRH}$ tone in vivo. Partial agonist effects of $\alpha$-helical CRH have been reported previously in vitro (Rainnie et al., 1992; Yu and Shinnick-Gallagher, 1998; Smart et al., 1999) and in vivo (Menzaghi et al., 1994; Borsody and Weiss, 1996). Nonetheless, the CRH antagonist still reduced the magnitude of the CRH-evoked increase in the LC FR. The possibility of a novel type of CRH receptor should be considered (Bittencourt and Sawchenko, 2000; Van Pett et al., 2000), although previous in vivo studies suggest that the receptor mediating the effect of $\mathrm{CRH}$ in the LC can be blocked by D-Phe-CRH (Curtis et al., 1994, 1997). The receptor subtype-specific antagonist CP154,526 did not cause a change in the basal FR but, because of its poor solubility, we could not evaluate whether the CRH effect could be completely blocked by this antagonist, and no clear dose-response relationship was observed with increasing doses of CP154,526. Nevertheless, CP154,526 did reduce the effect of CRH, suggesting that at least part of the response occurred via $\mathrm{CRH}_{1}$ receptors; this is consistent with recent evidence demonstrating $\mathrm{CRH}_{1}$ receptor immunoreactivity in the LC (Sauvage and Steckler, 2001; Fox et al., 2002; Xu et al., 2004) and the observation that systemic CP154,526 reduces intraventricular CRH-evoked increases in the LC FR (Schulz et al., 1996).

\section{Second messenger systems}

Consistent with previous reports that CAMP and PKA are necessary for spontaneous activity of LC neurons (Alreja and Aghajanian, 1991, 1995), intracellular administration of the cAMP antagonist/PKA inhibitor Rp-cAMP-S and the PKA inhibitor H89 both reduced the spontaneous discharge rate of LC neurons. However, only Rp-cAMP-S prevented the CRH-evoked activation of LC neurons. Both compounds, which have comparable molecular weights, were applied intracellularly through the recording electrode at sufficient concentrations $(\sim 400$-fold and 1000 -fold $K_{\mathrm{i}}$ for Rp-cAMP-S and H89, respectively) because they both decreased LC neuron discharge. Direct actions of cAMP on cellular conductances, such as $I_{\mathrm{H}}$ or cyclic nucleotide-gated channels, can occur independent of PKA (Pedarzani and Storm, 1995; Ingram and Williams, 1996; Chin et al., 2002). These actions can be prevented by cAMP antagonists, such as Rp-cAMP-S, but not by PKA inhibitors. Therefore, it appears that the effect of CRH on LC neurons is mediated by cAMP but not PKA.

\section{Relevance to stress-related psychiatric disorders}

The noradrenergic system of the LC has long been implicated in the pathophysiology of mood and anxiety disorders (Charney et al., 1995; Wong et al., 2000). Increased CSF levels of CRH have been reported in several studies of patients with major depression, post-traumatic stress disorder, obsessive compulsive disorder, and Tourette's syndrome (Arborelius et al., 1999). Furthermore, increased levels of CRH within the LC of depressed patients have recently been reported (Bissette et al., 2003), and chronic treatment with various antidepressants alters the interaction between CRH and LC neurons (Curtis and Valentino, 1994). Therefore, the direct link between the CRH and noradrenergic systems reported here further supports the notion that the interaction between these transmitters systems in the LC plays an important role in the pathophysiology of mood and anxiety disorders and may be a potential therapeutic target for their treatment.

\section{References}

Aghajanian GK, Rasmussen K (1989) Intracellular studies in the facial nucleus illustrating a simple new method for obtaining viable motoneurons in adult rat brain slices. Synapse 3:331-338.

Aghajanian GK, Wang YY (1987) Common alpha-2 and opiate effector mechanisms in the locus coeruleus: intracellular studies in brain slices. Neuropharmacology 26:793-799.

Aldenhoff JB (1986) Does corticotropin releasing factor act via a calciumdependent mechanism? Psychoneuroendocrinology 11:231-236.

Aldenhoff JB, Gruol DL, Rivier J, Vale W, Siggins GR (1983) Corticotropin releasing factor decreases postburst hyperpolarizations and excites hippocampal neurons. Science 221:875-877.

Alreja M, Aghajanian GK (1991) Pacemaker activity of locus coeruleus neurons: whole-cell recordings in brain slices show dependence on cAMP and protein kinase A. Brain Res 556:339-343.

Alreja M, Aghajanian GK (1994) QX-314 blocks the potassium but not the sodium-dependent component of the opiate response in locus coeruleus neurons. Brain Res 639:320-324.

Alreja M, Aghajanian GK (1995) Use of the whole-cell patch-clamp method in studies on the role of cAMP in regulating the spontaneous firing of locus coeruleus neurons. J Neurosci Methods 59:67-75.

Andrade R, Vandermaelen CP, Aghajanian GK (1983) Morphine tolerance and dependence in the locus coeruleus: single cell studies in brain slices. Eur J Pharmacol 91:161-169.

Arborelius L, Owens MJ, Plotsky PM, Nemeroff CB (1999) The role of corticotropin-releasing factor in depression and anxiety disorders. J Endocrinol 160:1-12.

Bale TL, Vale WW (2004) CRF and CRF receptors: role in stress responsivity and other behaviors. Annu Rev Pharmacol Toxicol 44:525-557.

Bissette G, Klimek V, Pan J, Stockmeier C, Ordway G (2003) Elevated concentrations of CRF in the locus coeruleus of depressed subjects. Neuropsychopharmacology 28:1328-1335.

Bittencourt JC, Sawchenko PE (2000) Do centrally administered neuropeptides access cognate receptors?: an analysis in the central corticotropinreleasing factor system. J Neurosci 20:1142-1156.

Blank T, Nijholt I, Grammatopoulos DK, Randeva HS, Hillhouse EW, Spiess J (2003) Corticotropin-releasing factor receptors couple to multiple G-proteins to activate diverse intracellular signaling pathways in mouse hippocampus: role in neuronal excitability and associative learning. J Neurosci 23:700-707.

Borsody MK, Weiss JM (1996) Influence of corticotropin-releasing hormone on electrophysiological activity of locus coeruleus neurons. Brain Res 724:149-168. 
Brown JE, Muller KJ, Murray G (1971) Reversal potential for an electrophysiological event generated by conductance changes: mathematical analysis. Science 174:318.

Bundey RA, Kendall DA (1999) Inhibition of receptor-mediated calcium responses by corticotrophin-releasing hormone in the CATH. a cell line. Neuropharmacology 38:39-47.

Chalmers DT, Lovenberg TW, De Souza EB (1995) Localization of novel corticotropin-releasing factor receptor (CRF2) mRNA expression to specific subcortical nuclei in rat brain: comparison with CRF1 receptor mRNA expression. J Neurosci 15:6340-6350.

Chappell PB, Smith MA, Kilts CD, Bissette G, Ritchie J, Anderson C, Nemeroff CB (1986) Alterations in corticotropin-releasing factor-like immunoreactivity in discrete rat brain regions after acute and chronic stress. J Neurosci 6:2908-2914.

Charney DS, Bremner JD, Redmond Jr DE (1995) Noradrenergic neural substrates for anxiety and fear. In: Psychopharmacology: the fourth generation of progress (Bloom FE, Kupfer DJ, eds), pp 387-395. New York: Raven.

Chin KV, Yang WL, Ravatn R, Kita T, Reitman E, Vettori D, Cvijic ME, Shin M, Iacono L (2002) Reinventing the wheel of cyclic AMP: novel mechanisms of cAMP signaling. Ann NY Acad Sci 968:49-64.

Cibelli G, Corsi P, Diana G, Vitiello F, Thiel G (2001) Corticotropinreleasing factor triggers neurite outgrowth of a catecholaminergic immortalized neuron via cAMP and MAP kinase signalling pathways. Eur J Neurosci 13:1339-1348.

Conti LH, Foote SL (1995) Effects of pretreatment with corticotropinreleasing factor on the electrophysiological responsivity of the locus coeruleus to subsequent corticotropin-releasing factor challenge. Neuroscience 69:209-219.

Curtis AL, Valentino RJ (1994) Corticotropin-releasing factor neurotransmission in locus coeruleus: a possible site of antidepressant action. Brain Res Bull 35:581-587.

Curtis AL, Grigoriadis DE, Page ME, Rivier J, Valentino RJ (1994) Pharmacological comparison of two corticotropin-releasing factor antagonists: in vivo and in vitro studies. J Pharmacol Exp Ther 268:359-365.

Curtis AL, Lechner SM, Pavcovich LA, Valentino RJ (1997) Activation of the locus coeruleus noradrenergic system by intracoerulear microinfusion of corticotropin-releasing factor: effects on discharge rate, cortical norepinephrine levels and cortical electroencephalographic activity. J Pharmacol Exp Ther 281:163-172.

Curtis AL, Pavcovich LA, Valentino RJ (1999) Long-term regulation of locus ceruleus sensitivity to corticotropin-releasing factor by swim stress. J Pharmacol Exp Ther 289:1211-1219.

Danbolt NC (2001) Glutamate uptake. Prog Neurobiol 65:1-105.

Dautzenberg FM, Hauger RL (2002) The CRF peptide family and their receptors: yet more partners discovered. Trends Pharmacol Sci 23:71-77.

Dunn AJ, Berridge CW (1990) Physiological and behavioral responses to corticotropin-releasing factor administration: is CRF a mediator of anxiety or stress responses? Brain Res Brain Res Rev 15:71-100.

Egan TM, Henderson G, North RA, Williams JT (1983) Noradrenalinemediated synaptic inhibition in rat locus coeruleus neurones. J Physiol (Lond) 345:477-488.

Finlay JM, Jedema HP, Rabinovic AD, Mana MJ, Zigmond MJ, Sved AF (1997) Impact of corticotropin-releasing hormone on extracellular norepinephrine in prefrontal cortex after chronic cold stress. J Neurochem 69:144-150.

Fox K, Wolff I, Curtis A, Pernar L, Van Bockstaele EJ, Valentino RJ (2002) Multiple lines of evidence for the existence of corticotropin-releasing factor (CRH) receptors on locus coeruleus (LC) neurons. Soc Neurosci Abstr 28:637.9.

Grammatopoulos DK, Randeva HS, Levine MA, Kanellopoulou KA, Hillhouse EW (2001) Rat cerebral cortex corticotropin-releasing hormone receptors: evidence for receptor coupling to multiple G-proteins. J Neurochem 76:509-519.

Hauger RL, Olivares-Reyes JA, Braun S, Catt KJ, Dautzenberg FM (2003a) Mediation of corticotropin releasing factor type 1 receptor phosphorylation and desensitization by protein kinase $\mathrm{C}$ : a possible role in stress adaptation. J Pharmacol Exp Ther 306:794-803.

Hauger RL, Grigoriadis DE, Dallman MF, Plotsky PM, Vale WW, Dautzenberg FM (2003b) International Union of Pharmacology. XXXVI. Current status of the nomenclature for receptors for corticotropin-releasing factor and their ligands. Pharmacol Rev 55:21-26.
Illes P, Regenold JT (1990) Interaction between neuropeptide Y and noradrenaline on central catecholamine neurons. Nature 344:62-63.

Illes P, Finta EP, Nieber K (1993) Neuropeptide Y potentiates via Y2receptors the inhibitory effect of noradrenaline in rat locus coeruleus neurones. Naunyn-Schmiedebergs Arch Pharmacol 348:546-548.

Ingram SL, Williams JT (1996) Modulation of the hyperpolarizationactivated current (Ih) by cyclic nucleotides in guinea-pig primary afferent neurons. J Physiol (Lond) 492:97-106.

Inoue M, Nakajima S, Nakajima Y (1988) Somatostatin induces an inward rectification in rat locus coeruleus neurones through a pertussis toxinsensitive mechanism. J Physiol (Lond) 407:177-198.

Ivanov A, Aston-Jones G (1995) Extranuclear dendrites of locus coeruleus neurons: activation by glutamate and modulation of activity by alpha adrenoceptors. J Neurophysiol 74:2427-2436.

Ivanov A, Aston-Jones G (2000) Hypocretin/orexin depolarizes and decreases potassium conductance in locus coeruleus neurons. NeuroReport 11:1755-1758.

Jedema HP, Grace AA (2003) Chronic exposure to cold stress alters electrophysiological properties of locus coeruleus neurons recorded in vitro. Neuropsychopharmacology 28:63-72.

Jedema HP, Finlay JM, Sved AF, Grace AA (2001) Chronic cold exposure potentiates CRH-evoked increases in electrophysiologic activity of locus coeruleus neurons. Biol Psychiatry 49:351-359.

Kirby LG, Rice KC, Valentino RJ (2000) Effects of corticotropin-releasing factor on neuronal activity in the serotonergic dorsal raphe nucleus. Neuropsychopharmacology 22:148-162.

Koyano K, Velimirovic BM, Grigg JJ, Nakajima S, Nakajima Y (1993) Two signal transduction mechanisms of substance P-induced depolarization in locus coeruleus neurons. Eur J Neurosci 5:1189-1197.

Kuryshev YA, Childs GV, Ritchie AK (1996a) Corticotropin-releasing hormone stimulates $\mathrm{Ca}^{2+}$ entry through L- and P-type $\mathrm{Ca}^{2+}$ channels in rat corticotropes. Endocrinology 137:2269-2277.

Kuryshev YA, Childs GV, Ritchie AK (1996b) Corticotropin releasing hormone modulation of a hyperpolarization-activated current $\left(I_{\mathrm{H}}\right)$. Soc Neurosci Abstr 22:1249.

Kuryshev YA, Haak L, Childs GV, Ritchie AK (1997) Corticotropin releasing hormone inhibits an inwardly rectifying potassium current in rat corticotropes. J Physiol (Lond) 502:265-279.

Melia KR, Duman RS (1991) Involvement of corticotropin-releasing factor in chronic stress regulation of the brain noradrenergic system. Proc Natl Acad Sci USA 88:8382-8386.

Menzaghi F, Howard RL, Heinrichs SC, Vale W, Rivier J, Koob GF (1994) Characterization of a novel and potent corticotropin-releasing factor antagonist in rats. J Pharmacol Exp Ther 269:564-572.

Millan MA, Jacobowitz DM, Hauger RL, Catt KJ, Aguilera G (1986) Distribution of corticotropin-releasing factor receptors in primate brain. Proc Natl Acad Sci USA 83:1921-1925.

Nicholson C, Tao L (1993) Hindered diffusion of high molecular weight compounds in brain extracellular microenvironment measured with integrative optical imaging. Biophys J 65:2277-2290.

Osmanovic SS, Shefner SA (1993) Calcium-activated hyperpolarizations in rat locus coeruleus neurons in vitro. J Physiol (Lond) 469:89-109.

Osmanovic SS, Shefner SA, Brodie MS (1990) Functional significance of the apamin-sensitive conductance in rat locus coeruleus neurons. Brain Res 530:283-289.

Owens MJ, Nemeroff CB (1991) Physiology and pharmacology of corticotropin-releasing factor. Pharmacol Rev 43:425-473.

Palamarchouk VS, Zhang J, Zhou G, Swiergiel AH, Dunn AJ (2000) Hippocampal norepinephrine-like voltammetric responses following infusion of corticotropin-releasing factor into the locus coeruleus. Brain Res Bull 51:319-326.

Palamarchouk VS, Swiergiel AH, Dunn AJ (2002) Hippocampal noradrenergic responses to CRF injected into the locus coeruleus of unanesthetized rats. Brain Res 950:31-38.

Pavcovich LA, Valentino RJ (1997) Regulation of a putative neurotransmitter effect of corticotropin-releasing factor: effects of adrenalectomy. J Neurosci 17:401-408.

Pedarzani P, Storm JF (1995) Protein kinase A-independent modulation of ion channels in the brain by cyclic AMP. Proc Natl Acad Sci USA 92:11716-11720.

Pieribone VA, Xu ZQ, Zhang X, Grillner S, Bartfai T, Hokfelt T (1995) Ga- 
lanin induces a hyperpolarization of norepinephrine-containing locus coeruleus neurons in the brainstem slice. Neuroscience 64:861-874.

Potter E, Sutton S, Donaldson C, Chen R, Perrin M, Lewis K, Sawchenko PE, Vale W (1994) Distribution of corticotropin-releasing factor receptor mRNA expression in the rat brain and pituitary. Proc Natl Acad Sci USA 91:8777-8781.

Primus RJ, Yevich E, Baltazar C, Gallager DW (1997) Autoradiographic localization of CRF1 and CRF2 binding sites in adult rat brain. Neuropsychopharmacology 17:308-316.

Rainnie DG, Fernhout BJ, Shinnick-Gallagher P (1992) Differential actions of corticotropin releasing factor on basolateral and central amygdaloid neurones, in vitro. J Pharmacol Exp Ther 263:846-858.

Sanchez MM, Young LJ, Plotsky PM, Insel TR (1999) Autoradiographic and in situ hybridization localization of corticotropin-releasing factor 1 and 2 receptors in nonhuman primate brain. J Comp Neurol 408:365-377.

Sauvage M, Steckler T (2001) Detection of corticotropin-releasing hormone receptor 1 immunoreactivity in cholinergic, dopaminergic and noradrenergic neurons of the murine basal forebrain and brainstem nuclei-potential implication for arousal and attention. Neuroscience 104:643-652.

Schulz DW, Mansbach RS, Sprouse J, Braselton JP, Collins J, Corman M, Dunaiskis A, Faraci S, Schmidt AW, Seeger T, Seymour P, Tingley 3rd FD, Winston EN, Chen YL, Heym J (1996) CP-154,526: a potent and selective nonpeptide antagonist of corticotropin releasing factor receptors. Proc Natl Acad Sci USA 93:10477-10482.

Shen KZ, North RA (1992a) Muscarine increases cation conductance and decreases potassium conductance in rat locus coeruleus neurones. J Physiol (Lond) 455:471-485.

Shen KZ, North RA (1992b) Substance P opens cation channels and closes potassium channels in rat locus coeruleus neurons. Neuroscience 50:345-353.

Siggins GR, Gruol D, Aldenhoff J, Pittman Q (1985) Electrophysiological actions of corticotropin-releasing factor in the central nervous system. Fed Proc 44:237-242.

Smagin GN, Swiergiel AH, Dunn AJ (1995) Corticotropin-releasing factor administered into the locus coeruleus, but not the parabrachial nucleus, stimulates norepinephrine release in the prefrontal cortex. Brain Res Bull 36:71-76.

Smagin GN, Zhou J, Harris RB, Ryan DH (1997) CRF receptor antagonist attenuates immobilization stress-induced norepinephrine release in the prefrontal cortex in rats. Brain Res Bull 42:431-434.

Smart D, Coppell A, Rossant C, Hall M, McKnight AT (1999) Characterisation using microphysiometry of CRF receptor pharmacology. Eur J Pharmacol 379:229-235.

Swanson LW, Sawchenko PE, Rivier J, Vale WW (1983) Organization of ovine corticotropin-releasing factor immunoreactive cells and fibers in the rat brain: an immunohistochemical study. Neuroendocrinology 36:165-186.

Thiel G, Cibelli G (1999) Corticotropin-releasing factor and vasoactive intestinal polypeptide activate gene transcription through the cAMP signaling pathway in a catecholaminergic immortalized neuron. Neurochem Int 34:183-191.

Travagli RA, Wessendorf M, Williams JT (1996) Dendritic arbor of locus coeruleus neurons contributes to opioid inhibition. J Neurophysiol 75:2029-2035.

Vale W, Spiess J, Rivier C, Rivier J (1981) Characterization of a 41-residue ovine hypothalamic peptide that stimulates secretion of corticotropin and beta-endorphin. Science 213:1394-1397.
Valentino RJ, Foote SL, Aston-Jones G (1983) Corticotropin-releasing factor activates noradrenergic neurons of the locus coeruleus. Brain Res 270:363-367.

Valentino RJ, Page ME, Curtis AL (1991) Activation of noradrenergic locus coeruleus neurons by hemodynamic stress is due to local release of corticotropin-releasing factor. Brain Res 555:25-34.

Valentino RJ, Page M, Van Bockstaele E, Aston-Jones G (1992) Corticotropin-releasing factor innervation of the locus coeruleus region: distribution of fibers and sources of input. Neuroscience 48:689-705.

Valentino RJ, Foote SL, Page ME (1993) The locus coeruleus as a site for integrating corticotropin-releasing factor and noradrenergic mediation of stress responses. Ann NY Acad Sci 697:173-188.

Van Bockstaele EJ, Colago EE (1996) Ultrastructural localization of the kainate selective glutamate receptor in noradrenergic perikarya and dendrites of the nucleus locus coeruleus in the rat brain. Brain Res 732:223-231.

Van Bockstaele EJ, Peoples J, Valentino RJ (1999) A. E. Bennett Research Award. Anatomic basis for differential regulation of the rostrolateral perilocus coeruleus region by limbic afferents. Biol Psychiatry 46:1352-1363.

Van Bockstaele EJ, Bajic D, Proudfit H, Valentino RJ (2001) Topographic architecture of stress-related pathways targeting the noradrenergic locus coeruleus. Physiol Behav 73:273-283.

Van Pett K, Viau V, Bittencourt JC, Chan RK, Li HY, Arias C, Prins GS, Perrin M, Vale W, Sawchenko PE (2000) Distribution of mRNAs encoding $\mathrm{CRF}$ receptors in brain and pituitary of rat and mouse. J Comp Neurol 428:191-212.

Velimirovic BM, Koyano K, Nakajima S, Nakajima Y (1995) Opposing mechanisms of regulation of a G-protein-coupled inward rectifier K+ channel in rat brain neurons. Proc Natl Acad Sci USA 92:1590-1594.

Wang YY, Aghajanian GK (1990) Excitation of locus coeruleus neurons by vasoactive intestinal peptide: role of a cAMP and protein kinase A. J Neurosci 10:3335-3343.

Williams JT, North RA, Shefner SA, Nishi S, Egan TM (1984) Membrane properties of rat locus coeruleus neurones. Neuroscience 13:137-156.

Williams JT, Henderson G, North RA (1985) Characterization of alpha 2-adrenoceptors which increase potassium conductance in rat locus coeruleus neurones. Neuroscience 14:95-101.

Williams JT, North RA, Tokimasa T (1988) Inward rectification of resting and opiate-activated potassium currents in rat locus coeruleus neurons. J Neurosci 8:4299-4306.

Wong ML, Kling MA, Munson PJ, Listwak S, Licinio J, Prolo P, Karp B, McCutcheon IE, Geracioti Jr TD, DeBellis MD, Rice KC, Goldstein DS, Veldhuis JD, Chrousos GP, Oldfield EH, McCann SM, Gold PW (2000) Pronounced and sustained central hypernoradrenergic function in major depression with melancholic features: relation to hypercortisolism and corticotropin-releasing hormone. Proc Natl Acad Sci USA 97:325-330.

Xu GP, Van Bockstaele E, Reyes B, Bethea T, Valentino RJ (2004) Chronic morphine sensitizes the brain norepinephrine system to corticotropinreleasing factor and stress. J Neurosci 24:8193-8197.

Yu B, Shinnick-Gallagher P (1998) Corticotropin-releasing factor increases dihydropyridine- and neurotoxin-resistant calcium currents in neurons of the central amygdala. J Pharmacol Exp Ther 284:170-179.

Zeng J, Kitayama I, Yoshizato H, Zhang K, Okazaki Y (2003) Increased expression of corticotropin-releasing factor receptor mRNA in the locus coeruleus of stress-induced rat model of depression. Life Sci 73:1131-1139. 